\title{
Kualitas Pelayanan Penyuluhan Pertanian dan Kepuasan Petani dalam Pengembangan Usahatani (Kasus di Desa Sukadamai Kecamatan Dramaga Kabupaten Bogor)
}

\author{
Agricultural Extension Service Quality and Satisfaction of Farmers in Developing Farming \\ (Case in Sukadamai village Dramaga District Bogor Regency)
}

\author{
Meilvis E. Tahitu ${ }^{1}$ \\ ${ }^{1}$ Fakultas Pertanian Universitas Pattimura Ambon, Maluku
}

\begin{abstract}
Agricultural extension has significance in changing the behavior of farmers into a better, but the it will be able to realize the goal of agricultural extension if done well and qualified. This study aims to assess the quality of agricultural extension in Sukadamai Village and its relationship with satisfaction and capacity of farmers. The study was designed as a research survey with 38 respondents taking with simple random sampling from 50 farmers in the Sukadamai. Data analysis was conducted by descriptive statistics to describe the distribution of respondents in each measured variable, whereas inferential statistics are used to see the relationship between the variables, in this case used Spearman Rank Correlation analysis. The results showed that formal education and the length of farming relate to assessment of farmers to agricultural extension methods; farm land area associated with the assessment of farmers to agricultural extension agent appearance; the intensity of the visiting agricultural extension agent, agricultural extension materials and methods associated with assessment of the accuracy of agricultural extension; accuracy of extension and methods related to the ability of farmers to identify potential farms, while farmers' personal characteristics not related to the capacity of farmers.
\end{abstract}

Keywords: Quality of extension services, farmer satisfaction, the capacity of farmers, farm development

\begin{abstract}
Abstrak
Penyuluhan pertanian memiliki arti penting dalam merubah perilaku petani ke arah yang lebih baik, namun penyuluhan pertanian akan mampu mewujudkan tujuan penyuluhan pertanian jika penyuluhan pertanian dilakukan dengan baik dan juga berkualitas. Penelitian ini bertujuan untuk mengkaji kualitas pelayanan penyuluhan pertanian di Desa Sukadamai dan hubungannya dengan kepuasan dan kapasitas petani sebagai sasaran penyuluhan tersebut. Penelitian dirancang sebagai penelitian survey dengan mengambil 38 orang petani sebagai responden secara acak sederhana dari 50 orang petani yang ada di Desa Sukadamai. Analisis data dilakukan secara statistik deskriptif untuk menggambarkan sebaran responden pada setiap peubah yang diukur; sedangkan statistik inferensial digunakan untuk melihat hubungan antar peubah penelitian, dalam hal ini digunakan analisis Korelasi Rank Spearman. Hasil penelitian menunjukkan bahwa pendidikan formal dan lama berusahatani yang dimiliki petani berhubungan dengan penilaian petani terhadap metode penyuluhan pertanian; luas lahan usahatani berhubungan dengan penilaian petani terhadap penampilan penyuluh pertanian; intensitas kunjungan penyuluh pertanian, materi dan metode penyuluhan pertanian berhubungan dengan penilaian petani terhadap ketepatan pelayanan penyuluhan pertanian; ketepatan pelayanan penyuluhan dan metode penyuluhan pertanian berhubungan dengan kemampuan petani dalam mengidentifikasi potensi usahatani; sedangkan karakteristik pribadi petani tidak berhubungan dengan kapasitas petani.
\end{abstract}

Kata kunci: Kualitas penyuluhan, kepuasan petani, kapasitas petani, pengembangan usahatani

\section{Pendahuluan}

Undang-undang No.16 Tahun 2006 tentang Sistem Penyuluhan Pertanian, Perikanan, dan juga Kehutanan (UUSP3K) mensyaratkan perlunya sumberdaya manusia berkualitas, andal, serta berkemampuan manajerial, kewirausahaan serta organisasi bisins agar peran sektor pertanian dapat ditingkatkan. Sehubungan dengan hal itu, pemerintah berkewajiban menyelenggarakan penyuluhan di bidang pertanian. Penyelenggaraan kegiatan penyuluhan pertanian juga mempunyai kedudukan yang sangat strategis dalam proses pembangunan pertanian, khususnya dalam pengembangan kemampuan, pengetahuan, keterampilan, serta sikap pelaku utama dan pelaku usaha. Melalui penyuluhan pertanian, pelaku utama dan pelaku usaha di bidang pertanian diharapkan mau dan mampu menolong dan mengorganisasikan diri dalam mengakses informasi pasar, teknologi, permodalan, dan sumberdaya lainnya, sebagai upaya untuk meningkatkan produktivitas, efisiensi usaha, pendapatan, dan kesejahteraannya, serta meningkatkan kesadaran dalam pelestarian fungsi lingkungan hidup (UUSP3K, 2006).

Kegiatan penyuluhan pertanian perlu ditata dan dikembangkan sedemikian rupa agar harapan, kepuasan

${ }^{1}$ Korespondensi penulis 
dan kapasitas petani sebagai sasaran penyuluhan pertanian dapat terpenuhi sebagaimana mestinya. McCaslin dan Tibezinda (Tiraieyari et al., 2010; Abubakar dan Siregar, 2010) menyatakan bahwa pelaksanaan kegiatan penyuluhan pertanian merupakan serangkaian proses yang berkelanjutan sesuai kebutuhan petani; untuk itu, materi dan metode penyuluhan pertanian merupakan bagian dari kualitas kegiatan penyuluhan pertanian. Kualitas penyuluhan dapat diketahui dengan cara membandingkan kepuasan para petani atas layanan yang diterima dengan layanan yang diharapkan petani. Lebih jauh Abubakar dan Siregar (2010) menjelaskan bahwa kegiatan penyuluhan pertanian diharapkan mampu menjembatani berbagai fenomena-fenomena yang terjadi di lingkungan petani dengan perkembangan ilmu pengetahuan, baik yang bersifat temporer maupun bersifat tetap. Keberadaan penyuluh pertanian sebagai ujung tombak dari proses penyelenggaraan pembangunan pertanian diharapkan mampu menyampaikan pesanpesan inovasi sesuai kebutuhan para petani serta mampu untuk menerjemahkan kebijakan dari pemerintah terkait dengan pembangunan pertanian. Dengan kata lain, penyuluhan pertanian diharapkan mampu memenuhi kebutuhan petani untuk mengembangkan usahataninya sehingga petani merasa puas.

Di Indonesia tugas pokok dan fungsi penyuluh pertanian adalah melakukan kegiatan penyuluhan pertanian untuk dapat mengembangkan kemampuan petani dalam menguasai, memanfaatkan dan menerapkan teknologi baru sehingga mampu bertani lebih baik, berusaha lebih menguntungkan serta membina kehidupan berkeluarga yang lebih sejahtera. Penyuluh pertanian dituntut untuk memiliki kemampuan yang memadai dalam menetapkan materi sesuai kebutuhan petani serta dapat menggunakan metode penyuluhan yang sesuai dengan keadaan petani. Materi penyuluhan merupakan segala pesan yang ingin dikomunikasikan oleh penyuluh kepada masyarakat sasarannya.

Havelock dalam Mardikanto (1993) telah mengemukakan ada empat tipe pesan yang saling berhubungan, yaitu: pengetahuan dasar atau ilmu-ilmu dasar sebagai hasil dari penelitian dasar, hasil risetterapan dan pengembangannya, pengetahuan praktis sebagai hasil dari pengalaman dan pesan dari pengguna atau masyarakat luas. Menurut Mardikanto (1993), dalam proses penyuluhan perlu dirinci akan ragam pokok bahasan yang disuluhkan dan juga turut memperhatikan hal-hal lain yang berkaitan dengan upaya memperbaiki kesejahteraan. Ragam pokok bahasan dalam kegiatan penyuluhan mencakup: (1) budidaya beserta materi yang berkaitan dengan teknologi pasca panen, (2) ekonomi pertanian yang terdiri dari pengelolaan usahatani, ekonomi produksi, pemasaran hasil, pembiayaan, perencanaan, akuntansi dan kewirausahaan, (3) pengelolaan rumah tangga petani, terdiri dari pengenalan tentang makna hubungan usahatani dengan ekonomi rumah tangga dan pengelolaan sumberdaya dan evaluasi pengelolaan ekonomi rumah tangga, (4) pelembagaan petani dan juga (5) politik pembangunan pertanian.

Dalam hubungannya dengan metode-metode dalam penyuluhan, untuk meningkatkan efektivitas metode, pemilihan dan penggunaan metode harus didasarkan atas kondisi para petani, yaitu perhatian, minat, kepercayaan, hasrat, tindakan dan kepuasan. Kondisi petani penting diperhatikan agar penyuluhan yang dilakukan dapat ikut membantu para petani memenuhi kebutuhannya, sehingga dengan demikian menimbulkan kepuasan bagi petani dan penyuluhan seperti itu merupakan penyuluhan yang berkualitas.

Puspadi (2003) menjelaskan bahwa pada hakekatnya kualitas dari kegiatan penyuluhan pertanian merupakan fungsi kualitas sumberdaya manusia penyuluh pertanian. Kualitas kegiatan penyuluhan pertanian diukur dengan lima indikator, yaitu: (1) materi penyuluhan pertanian, (2) domain yang disentuh dalam melaksanakan rangkaian kegiatan penyuluhan pertanian, (3) memfasilitasi keputusan-keputusan dari petani, (4) keberpihakan kepada petani, dan (5) intensitas kunjungan penyuluh pertanian ke wilayah binaannya. Kualitas pelayanan penyuluhan diharapkan dapat menimbulkan kepuasan bagi petani yang selanjutnya akan bermanfaat dalam upaya ikut meningkatkan kapasitasnya.

Kepuasan para petani terhadap jasa penyuluhan utamanya akan ditentukan oleh tingkat terpenuhinya kebutuhan petani oleh penyuluhan yang ada yang selanjutnya dapat meningkatkan kapasitas petani. Kapasitas berkaitan dengan kinerja yang dapat dicapai seseorang ataupun organisasi (Liou 2004; Fatchiya 2010); Syahyuti 2006). Kapasitas yang tinggi akan menghasilkan kinerja yang tinggi dan sebaliknya. Subagio et al. (2008) menyatakan bahwa kapasitas petani adalah daya-daya yang dimiliki pribadi seorang petani untuk dapat menetapkan tujuan usahatani secara tepat dan mencapai tujuan yang telah ditetapkan dengan cara yang tepat pula.

Kapasitas diri merupakan perwujudan dari aspek pengetahuan, aspek sikap, dan keterampilan yang 
terinternalisasi dalam diri seseorang (Tjitropranoto, 2005; Subagio et al., 2008). Disamping aspek pengetahuan, sikap dan juga keterampilan, kapasitas diri menurut Tjitropranoto (2005) juga dibentuk oleh rasa percaya diri, komitmen, dan kewirausahaan; sedangkan untuk kapasitas sumberdaya dan sarana meliputi lahan, modal usaha, dan pasar.

Bagi para petani di Desa Sukadamai, kehadiran para penyuluh sangat diharapkan, terutama untuk membantu para petani dalam memecahkan masalah yang dihadapi, namun pada kenyataannya masih belum semua permasalahan petani dapat diatasi. Hal ini menimbulkan berbagai tingkat kepuasan pada para petani terhadap penyelenggaraan penyuluhan yang ada. Beragamnya tingkat kepuasan petani menggambarkan tujuan penyuluhan pertanian belum sepenuhnya tercapai. Sehubungan dengan itu, diperlukan suatu kajian tentang kualitas pelayanan penyuluh pertanian dan kepuasan petani terhadap pelayanan penyuluhan tersebut serta kaitannya dengan kapasitas petani dalam pengembangan usahatani di desa tersebut dengan fokus permasalahan adalah: (1) bagaimanakah kualitas dari pelayanan penyuluhan pertanian di Desa Sukadamai?, (2) bagaimanakah hubungan yang ada antara karakteristik pribadi petani dengan kualitas pelayanan penyuluhan, tingkat kepuasan petani dan kapasitas petani dalam berusahatani?, (3) bagaimanakah hubungan antara kualitas pelayanan pada penyuluhan dengan tingkat kepuasan para petani dan kapasitas petani dalam berusahatani?, dan (4) bagaimana hubungan antara kepuasan petani dengan kapasitas petani dalam berusahatani?

Mengacu pada permasalahan tersebut, maka tujuan penelitian ini adalah: (1) mengkaji kualitas pelayanan penyuluhan pertanian di Desa Sukadamai, (2) mengkaji hubungan antara karakteristik pribadi petani dengan kualitas pelayanan penyuluhan pertanian, tingkat kepuasan petani dan kapasitas petani dalam berusahatani, (3) mengkaji hubungan kualitas pelayanan penyuluhan dengan tingkat kepuasan dan kapasitas petani dalam berusahatani, dan (4) mengkaji hubungan tingkat kepuasan dengan kapasitas petani dalam berusahatani.

\section{Metode Penelitian}

Penelitian ini berlangsung sejak awal November 2011 sampai awal Desember di Desa
Sukadamai Kecamatan Dramaga, Kabupaten Bogor, Provinsi Jawa Barat. Lokasi penelitian ini ditentukan dengan pertimbangan lokasi tersebut ialah desa binaan dari LPM-IPB, mudah dijangkau serta merupakan salah satu wilayah binaan dari BP3K Kecamatan Dramaga Kabupaten Bogor. Populasi dalam penelitian ini adalah semua petani tanaman pangan yang berada di desa penelitian (Desa Sukadamai) yang berjumlah 50 orang. Pengambilan sampel dilakukan secara simple random sampling dengan jumlah sampel penelitian ditentukan dengan rumus Slovin dengan menggunakan $\mathrm{e}=8 \%$, sehingga diperoleh jumlah sampel adalah 38 orang.

Data yang dikumpulkan berupa data primer yang merupakan data-data utama yang digunakan untuk menjawab tujuan dari penelitian, sedangkan datadata sekunder dijadikan sebagai data pelengkap atau data penunjang. Data primer dipeoleh dari responden, sedangkan data-data sekunder diperoleh dari Kantor BP3K Kecamatan Dramaga, data Monografi Desa Sukadamai, dan berbagai bahan atau hasil penelitian yang berkaitan dengan penelitian ini. Analisis data mencakup: (1) analisis statistik deskriptif, dan juga dengan (2) analisis statistik inferensial. Analisis data deskriptif dilakukan melalui statistik deskriptif, yakni statistik yang berfungsi mendeskripsikan atau memberi gambaran terhadap obyek yang diteliti tanpa membuat kesimpulan yang berlaku untuk umum; sedangkan analisis statistik inferensial dilakukan dengan menggunakan rumus korelasi Rank Spearman.

\section{Hasil dan Pembahasan}

\section{Karakteristik Pribadi Petani}

Sebagian besar petani di desa Sukadamai berada pada usia muda sampai dewasa (Tabel 1). Persentase petani yang berusia tua ( $>55$ tahun) relatif lebih sedikit (26,32\%) dibandingkan dengan petani yang berusia muda dan dewasa ( $\leq 55$ tahun). Apabila dikaitkan dengan batasan usia kerja (angkatan kerja) menurut Badan Pusat Statistik (2009), yaitu pada kisaran usia 15 - 64 tahun digolongkan sebagai usia produktif, terlihat bahwa ada kecenderungan golongan penduduk usia muda khususnya pada usia $<40$ tahun tidak lagi berminat bekerja di sektor pertanian, namun bagi petani yang berusia $\geq 40$ tahun, sektor pertanian dipandang masih mampu memberikan harapan untuk penghidupan.

Proporsi terbesar petani $(68,42 \%)$ memiliki pendidikan formal hingga tingkat $\mathrm{SD}$, namun ada juga 
Jurnal Penyuluhan, September 2013 Vol. 9 No. 2

Tabel 1 Karakteristik Pribadi Petani Tanaman Pangan di Desa Sukadamai

\begin{tabular}{|c|c|c|c|}
\hline Sub Peubah & Kategori & Jumlah Responden (orang) & Persentase (\%) \\
\hline Umur (thn) & & $(\mathrm{n}=38)$ & \\
\hline Muda & $40-47$ & 10 & 26,32 \\
\hline Dewasa & $48-55$ & 18 & 47,37 \\
\hline Tua & $>55$ & 10 & 26,32 \\
\hline Interval & $40-63$ & & \\
\hline Rerata & 51,32 & & \\
\hline \multicolumn{4}{|l|}{ Pendidikan Formal (thn) } \\
\hline Rendah & $<6$ & 26 & 68,42 \\
\hline Sedang & $7-9$ & 8 & 21,05 \\
\hline Tinggi & $>9$ & 4 & 10,53 \\
\hline Interval & $4-12$ & & \\
\hline Rerata & 7,26 & & \\
\hline \multicolumn{4}{|l|}{ Pendidikan non Formal } \\
\hline Rendah & $0-1$ & 31 & 81,58 \\
\hline Sedang & $2-3$ & 7 & 18,42 \\
\hline Tinggi & $>3$ & 0 & 00,00 \\
\hline Interval & $0-3$ & & \\
\hline Rerata & 0,87 & & \\
\hline \multicolumn{4}{|l|}{ Lama Berusahatani (thn) } \\
\hline Pendek & $15-23$ & 11 & 28,95 \\
\hline Sedang & $24-32$ & 20 & 52,63 \\
\hline Panjang & $>32$ & 7 & 18,42 \\
\hline Interval & $15-38$ & & \\
\hline Rerata & 27,29 & & \\
\hline \multicolumn{4}{|c|}{ Keterdedahan dengan sumber informasi } \\
\hline Rendah & $0-1$ & 11 & 28,95 \\
\hline Sedang & $2-3$ & 25 & 65,79 \\
\hline Tinggi & $>3$ & 2 & 5,26 \\
\hline Interval & $0-4$ & & \\
\hline Rerata & 2,03 & & \\
\hline \multicolumn{4}{|l|}{ Luas Lahan (ha) } \\
\hline Sempit & $0,25-0,50$ & 22 & 57,89 \\
\hline Sedang & $0,51-0,76$ & 6 & 15,79 \\
\hline Luas & $>0,76$ & 10 & 26,32 \\
\hline Interval & $0,25-1,00$ & & \\
\hline Rerata & 0,63 & & \\
\hline
\end{tabular}

yang memilikipendidikan hingga tingkat menengah atas. Kenyataan menunjukkan bahwa terdapat kecenderungan tenaga muda pedesaan yang relatif terdidik kurang tertarik bekerja di sektor pertanian karena performa warga masyarakat yang bekerja di pertanian dinilai kurang menarik, baik dari sisi penampilan maupun perolehan pendapatan.
Pendidikan non formal masih menjadi tumpuan proses alih teknologi pertanian; namun demikian, sebagian besar petani di Desa Sukadamai dalam satu tahunterakhirini (tahun2010-2011) tidak selalu(jarang) mengikuti pendidikan non-formal (seperti pelatihan, penyuluhan lapang, atau juga plot demonstrasi), kalaupun ada hanya sebagian kecil petani yang biasanya 
Tabel 2 Kualitas Pelayanan Penyuluhan Pertanian di Desa Sukadamai

\begin{tabular}{|c|c|c|c|c|c|}
\hline No. & $\begin{array}{l}\text { Indikator Kualitas Pelayanan } \\
\text { Penyuluhan Pertanian }\end{array}$ & Kategori & $\begin{array}{l}\text { Jmlah Responden } \\
\qquad(\mathbf{n}=\mathbf{3 8})\end{array}$ & Persentase & Kisaran \\
\hline \multirow[t]{3}{*}{1} & Intensitas Kunjungan Penyuluh & Rendah $(\leq 6)$ & 11 & 28,95 & $5-9$ \\
\hline & & Sedang $(7-8)$ & 17 & 44,74 & \\
\hline & & Tinggi $(>8)$ & 10 & 26,31 & \\
\hline \multirow[t]{3}{*}{2} & Materi Penyuluhan & Kurang $(\leq 5)$ & 9 & 23,69 & $4-9$ \\
\hline & & Sedang $(6-7)$ & 21 & 55,26 & \\
\hline & & Baik $\quad(>7)$ & 8 & 21,05 & \\
\hline \multirow[t]{3}{*}{3} & Metode Penyuluhan & Kurang $(\leq 3)$ & 6 & 15,79 & $2-6$ \\
\hline & & Sedang $(4-5)$ & 26 & 68,42 & \\
\hline & & Baik $\quad(>5)$ & 6 & 15,79 & \\
\hline
\end{tabular}

Sumber: Analisis Data Primer, 2011

ikut, umumnya hanya sebatas ketua, sekretaris atau bendahara kelompok tani/kelompok wanita tani (KWT)/ Gabungan Kelompok Tani (Gapoktan).

Lama berusahatani merupakan salah satu faktor yang penting bagi petani di desa Sukadamai untuk dapat menjalankan dan mengembangkan kegiatan usahatani. Tabel 1 menunjukkan bahwa sebagian besar petani $(52,63 \%)$ memiliki lama berusahatani yang tergolong sedang ( $24-32$ tahun) yang sejalan dengan umur petani yang sebagian besar berumur dewasa hingga tua. Hal ini berarti lama berusahatani sejalan dengan pertambahan umur petani.

Faktor keterdedahan dengan sumber informasi sebagian besar petani $(65,79 \%)$ di desa Sukadamai tergolong sedang, artinya dalam setahun terakhir, petani hanya mengakses informasi sebanyak 2 hingga 3 kali, yang dilakukan melalui pertemuan dengan para penyuluh pertanian dan dari kalangan LPM/IPB melalui berbagai jenis kegiatan pengabdian masyarakat. Faktor lain yang juga sangat penting bagi seorang petani dalam berusahatani adalah lahan usahatani. Di desa Sukadamai, para petani mengusahakan lahan dengan luas berkisar 0,25 0,50 ha yang tergolong pada kategori sempit (Tabel 1). Sempitnya lahan yang diusahakan oleh sebagian besar dari petani $(57,89 \%)$ disebabkan lahan usaha telah dikonversi bagi kegiatan usaha lain, seperti bangunan kandang ternak, lahan untuk tambak, bahkan dijual untuk kebutuhan usaha non pertanian. Disamping luas lahan yang sempit, kendala lainnya yang dihadapi para petani adalah tingkat kesuburan lahan, ketersediaan tenaga kerja anggota keluarga, kecukupan modal, dan letak lahan yang tersebar di beberapa tempat (tidak berada dalam satu hamparan) sehingga menyulitkan pengelolaannya.

\section{Kualitas Pelayanan Penyuluhan Pertanian}

Tabel 2 menunjukkan bahwa ketiga peubah kualitas pelayanan penyuluhan pertanian di Desa Sukadamai sebagian besar petani menilainya berada pada kategori sedang. Intensitas kunjungan para penyuluh dirasakan masih tergolong sedang karena frekuensi

Tabel 3 Tingkat Kepuasan Petani

\begin{tabular}{lllccc}
\hline No. & $\begin{array}{c}\text { Tingkat Kepuasan } \\
\text { Petani }\end{array}$ & \multicolumn{1}{c}{ Kategori } & $\begin{array}{c}\text { Jumlah Responden } \\
(\mathbf{n}=\mathbf{3 8})\end{array}$ & Persentase & Kisaran \\
\hline 1 & Ketepatan & Rendah $(\leq 6)$ & 17 & 44,74 & $5-9$ \\
& Pelayanan & Sedang $(7-8)$ & 15 & 39,47 & \\
& Penyuluhan & Tinggi $(>8)$ & 6 & 15,79 & \\
2 & Penampilan & Kurang $(\leq 6)$ & 18 & 47,37 & $6-9$ \\
& Penyuluh & Sedang $(7-8)$ & 16 & 42,10 & \\
& Baik $(>8)$ & 4 & 10,53 & \\
\hline
\end{tabular}


Tabel 4 Kapasitas Petani dalam Berusahatani di Desa Sukadamai

\begin{tabular}{lllccc}
\hline No. & \multicolumn{1}{c}{ Kapasitas } & \multicolumn{1}{c}{$\begin{array}{c}\text { Jumlah } \\
\text { Responden } \\
(\mathbf{n}=\mathbf{3 8})\end{array}$} & Persentase & Kisaran \\
\hline 1 & Kemampuan & Kendah $(\leq 6)$ & 17 & 44,74 & $5-9$ \\
& Mengidentifikasi Potensi & Sedang $(7-8)$ & 18 & 47,37 & \\
& & Tinggi $(>8)$ & 3 & 7,89 & \\
\multirow{2}{*}{2} & Kemampuan Mengatasi & Kurang $(\leq 6)$ & 14 & 36,84 & $6-9$ \\
& Masalah & Sedang $(7-8)$ & 16 & 42,11 & \\
& & Baik $(>8)$ & 8 & 21,05 & \\
\hline
\end{tabular}

kunjungan 1 kali per minggu. Peningkatan intensitas kunjungan masih sulit dilakukan penyuluh karena wilayah binaan penyuluh yang tergolong luas sehingga harus membagi waktu kunjungan ke wilayah lain.

Materi penyuluhan yang disampaikan sudah tergolong memadai (sedang) oleh petani karena sudah dapat membantu petani dalam upaya mengembangkan usahataninya meskipun belum seluruh materi dapat memenuhi kebutuhan para petani. Metode penyuluhan yang diterapkan oleh penyuluh menurut penilaian petani masih perlu disesuaikan lagi dengan keadaan petani agar pelayanan penyuluhan lebih berkualitas. Petani menginginkan metode kunjungan lapangan atau usahatani lebih ditingkatkan sehingga para petani lebih leluasa untuk mengungkapkan berbagai masalah yang dihadapinya kepada penyuluh melalui tanya jawab atau berdiskusi sembari ikut melihat keadaan usahatani secara langsung, namun di sisi lain, banyak dari penyuluh mengalami keterbatasan waktu sehingga lebih banyak menggunakan metode ceramah dengan waktu diskusi yang terbatas melalui pendekatan yeng dilakukan terhadap masing-masing kelompok.

\section{Tingkat Kepuasan Petani}

Kualitas pelayanan penyuluhan yang ada di Desa Sukadamai menimbulkan tingkat kepuasan tersendiri bagi para petani, baik dalam hal ketepatan pelayanan penyuluhan maupun penampilan penyuluh. Tingkat kepuasan sebagian besar petani terhadap ketepatan pelayanan penyuluhan dan penampilan penyuluh tergolong rendah (Tabel 3). Selama ini pelayanan penyuluhan dirasakan belum memadai dalam membantu kebutuhan petani, terutama ketika petani menghadapi suatu jenis masalah yang benarbenar mengharapkan bantuan penyuluhan seringkali petani sulit untuk mencari bantuan, termasuk bantuan penyuluhan. Keadaan sulit ini lebih diperparah ketika petani tidak memiliki kemampuan untuk mengambil

Tabel 5 Koefisien Korelasi Karakteristik Pribadi Petani dengan Kualitas Pelayanan Penyuluhan Pertanian

\begin{tabular}{lccc}
\hline Kualitas Pelayanan & $\begin{array}{c}\text { Intensitas } \\
\text { Pelayanan } \\
\text { Penyuluhan } \\
\text { Pertanian }\left(\mathbf{X}_{2.1}\right)\end{array}$ & $\begin{array}{c}\text { Materi } \\
\text { Penyuluhan } \\
\text { Pertanian } \\
\left(\mathbf{X}_{2.2}\right)\end{array}$ & $\begin{array}{c}\text { Metode } \\
\text { Penyuluhan } \\
\text { Pertanian } \\
\left(\mathbf{X}_{2.3}\right)\end{array}$ \\
Pribadi Petani & 0,11024 & $-0,12571$ & $-0,21027$ \\
Umur $\left(\mathrm{X}_{1.1}\right)$ & $-0,00138$ & $-0,23146$ & $0,03650^{*}$ \\
Pendidikan formal $\left(\mathrm{X}_{1.2}\right)$ & 0,10135 & 0,17305 & 0,12694 \\
Pendidikan non formal $\left(\mathrm{X}_{1.3}\right)$ & 0,03055 & $-0,05887$ & 0,00894 \\
Keterdedahan sumber informasi $\left(\mathrm{X}_{1.4}\right)$ & $-0,10395$ & $-0,21077$ & $-0,35060^{*}$ \\
Lama usahatani $\left(\mathrm{X}_{1.5}\right)$ & 0,07194 & $-0,13917$ & 0,08848 \\
Luas lahan $\left(\mathrm{X}_{1.6}\right)$ & & & \\
\hline
\end{tabular}

Sumber: Analisis Data Primer, 2011 
Tabel 6 Korelasi Karakteristik Pribadi Petani dengan Tingkat Kepuasan Petani

\begin{tabular}{lcc}
\hline Karakteristik & $\begin{array}{c}\text { Tingkat Kepuasan } \\
\text { Ketepatan Pelayanan } \\
\text { Penyuluhan Pertanian } \\
\left(\mathbf{Y}_{1.1}\right)\end{array}$ & $\begin{array}{c}\text { Penampilan } \\
\text { Penyuluh Pertanian } \\
\left(\mathbf{Y}_{1.2}\right)\end{array}$ \\
Pribadi Petani & 0,11932 & $-0,12610$ \\
\hline Umur $\left(\mathrm{X}_{1.1}\right)$ & 0,14461 & $-0,15500$ \\
Pendidikan formal $\left(\mathrm{X}_{1.2}\right)$ & 0,14958 & 0,15071 \\
Pendidikan non formal $\left(\mathrm{X}_{1.3}\right)$ & 0,16831 & $-0,28013$ \\
Keterdedahan sumber informasi $\left(\mathrm{X}_{1.4}\right)$ & 0,11448 & $-0,01269$ \\
Lama usahatani $\left(\mathrm{X}_{1.5}\right)$ & $-0,09875$ & $-0,36092 *$ \\
Luas lahan $\left(\mathrm{X}_{1.6}\right)$ & & \\
\hline
\end{tabular}

keputusan secara cepat dan tepat sehingga yang dilakukan petani biasanya hanya pasrah pada keadaan. Penampilan penyuluh belum seperti yang diharapkan sebagian besar petani. Petani mengharapkan penyuluh juga berpenampilan mendekati seperti petani, dan bahkan pada kunjungan lapang, petani ingin penyuluh juga menjadi seperti petani sejati.

\section{Kapasitas Petani}

Kapasitas diri para petani, baik dalam mengidentifikasi potensi mereka maupun kemampuan mengatasi masalah tergolong sedang (Tabel 4). Sebagian besar petani menjalani kehidupan ibarat suatu rutinitas yang menyebabkan pengembangan kapasitas diri dan kapasitas usahatani berjalan lambat. Demikian pula dengan kemampuan dalam mengatasi masalah, ada masalah yang dapat diatasi petani, misalnya berkurangnya ketersediaan air yang menyebabkan petani secara cepat mengganti tanaman padi dengan mengusahakan tanaman pangan seperti jagung. Masalah yang belum dapat diatasi petani hingga kini adalah masalah pemasaran. Hingga kini petani seringkali menghadapi kesulitan dalam memasarkan produk usahataninya, dan jika terjual seringkali dengan harga yang menurut para petani sangat rendah.

\section{Hubungan Karakteristik Pribadi Petani dengan Kualitas Pelayanan Penyuluhan Pertanian}

Hasil analisis (Tabel 5) menunjukkan bahwa dari keenam sub peubah karakteristik pribadi petani, faktor pendidikan formal dan lama usahatani berhubungan nyata secara positif dengan penilaian petani terhadap kualitas metode pada penyuluhan pertanian. Petani yang memiliki pendidikan rendah cenderung mengharapkan kualitas pelayanan penyuluhan yang lebih baik karena petani hanya mengandalkan penyuluhan untuk membantunya dalam mengembangkan usahatani. Sehubungan dengan hal tersebut, petani menginginkan metode penyuluhan yang lebih dapat mendekatkan

Tabel 7 Koefisien Korelasi Karakteristik Pribadi Petani dengan Kapasitas Petani

\begin{tabular}{lcc}
\hline Kapasitas Petani & $\begin{array}{c}\text { Kamampuan } \\
\text { Mengidentifikasi } \\
\text { Potensi Usahatani } \\
\left(\mathbf{Y}_{\mathbf{2 . 1}}\right)\end{array}$ & $\begin{array}{c}\text { Kemampuan } \\
\text { Mengatasi Masalah } \\
\left(\mathbf{Y}_{\mathbf{2 . 2}}\right)\end{array}$ \\
\hline Umur $\left(\mathrm{X}_{1.1}\right)$ & $-0,19632$ & 0,01620 \\
Pendidikan formal $\left(\mathrm{X}_{1.2}\right)$ & 0,10131 & 0,10468 \\
Pendidikan non formal $\left(\mathrm{X}_{1.3}\right)$ & 0,09881 & 0,32014 \\
Keterdedahan sumber informasi $\left(\mathrm{X}_{1.4}\right)$ & 0,08164 & 0,07852 \\
Lama usahatani $\left(\mathrm{X}_{1.5}\right)$ & $-0,02798$ & 0,03754 \\
Luas lahan $\left(\mathrm{X}_{1.6}\right)$ & 0,25005 & 0,95050 \\
\hline
\end{tabular}

Sumber: Analisis Data Primer, 2011 
Tabel 8 Koefisien Korelasi Kualitas Pelayanan Penyuluhan Pertanian dengan Tingkat Kepuasan Petani

\begin{tabular}{|c|c|c|c|}
\hline \multicolumn{4}{|c|}{ Tingkat Kepuasan } \\
\hline $\begin{array}{l}\text { Kualitas Pelayanan } \\
\text { Penyuluhan Pertanian }\end{array}$ & Petani & $\begin{array}{c}\text { Ketepatan Pelayanan } \\
\text { Penyuluhan Pertanian } \\
\left(\mathbf{Y}_{1.1}\right)\end{array}$ & $\begin{array}{c}\text { Penampilan } \\
\text { Penyuluh Pertanian } \\
\left(\mathrm{Y}_{1.2}\right)\end{array}$ \\
\hline $\begin{array}{l}\text { Intensitas Kunjungan Penyuluh } \\
\text { Pertanian }\left(X_{2.1}\right)\end{array}$ & & $0,47471^{*}$ & 0,07312 \\
\hline Materi Penyuluhan $\left(\mathrm{X}_{2.2}\right)$ & & $0,39344^{*}$ & 0,37806 \\
\hline Metode Penyuluhan $\left(\mathrm{X}_{2.3}\right)$ & & $0,38298^{*}$ & 0,25939 \\
\hline
\end{tabular}

Sumber: Analisis Data Primer, 2011

dirinya dengan penyuluh. Berbeda halnya dengan petani yang berpendidikan lebih baik yang memiliki wawasan lebih luas sehingga tidak hanya menggantungkan diri pada kehadiran penyuluh pertanian.

Lama usahatani berhubungan negatif secara nyata dengan penilaian para petani terhadap kualitas dari metode penyuluhan pertanian, atau dengan kata lain semakin panjang tahun petani berusahatani, maka semakin rendah penilaian petani terhadap kualitas metode penyuluhan yang digunakan oleh penyuluh dan sebaliknya. Setiap waktu yang digunakan petani dalam berusahatani menghasilkan pengalaman berusahatani yang sangat penting bagi petani. Semakin lama seorang petani melakukan usahatani, penguasaannya terhadap usahatani semakin tinggi, apalagi usahatani yang dilakukannya cenderung tidak berubah. Dalam kondisi seperti itu, petani tidak terlalu membutuhkan kehadiran penyuluh dengan metode yang lebih bervariasi karena pada kenyataannya penyuluh juga kurang membawa hal-hal yang inovatif bagi para petani. Sebaliknya dengan petani yang lama berusahatani masih tergolong pendek maka petani tersebut akan cenderung lebih membutuhkan kehadiran penyuluh yang dapat membantunya dalam keadaan nyata sehingga metode penyuluhan diharapkan dapat lebih bersifat individu dan memberi keleluasan untuk dapat berdiskusi tentang masalah yang dihadapi petani.

Luas lahan berkorelasi positif secara nyata dengan penampilan para penyuluh pertanian, artinya semakin luas lahan yang diusahakan petani, maka kepuasan petani terhadap penampilan penyuluh pertanian semakin rendah, sebaliknya semakin sempit lahan yang diusahakan seorang petani, maka kepuasan para petani terhadap penampilan penyuluh pertanian semakin tinggi. Petani di Desa Sukadamai sebagian besarmasih mengusahakan lahan yang tergolong sempit dengan penilaian terhadap penampilan para penyuluh yang masih tergolong kurang. Pada umumnya petani dengan luas lahan sempit menghadapi masalah dalam proses mengambil keputusan, terutama keputusan untuk mengadopsi suatu inovasi. Terkait dengan hal tersebut, kehadiran penyuluh menjadi penting untuk para petani yang mengusahakan lahan lebih luas. Hal ini menyebabkan petani merasa kurang puas dengan penampilan penyuluh yang tidak dapat menjadi seperti petani sesungguhnya. Berbeda halna dengan petani dengan lahan sempit yang umumnya hanya pasrah pada keadaan sehingga kehadiran penyuluh dengan penampilan sebagaimana adanya juga tidak terlalu dipersoalkan.

Tabel 7 menunjukkan bahwa tidak ada satu pun dari variabel karakteristik pribadi para petani yang

Tabel 9 Koefisien Korelasi Kualitas Pelayanan Penyuluhan Pertanian dengan Kapasitas Petani

\begin{tabular}{|c|c|c|}
\hline $\begin{array}{ll}\text { Kualitas Pelayanan } \\
\text { Penyuluhan Pertanian }\end{array}$ & $\begin{array}{l}\text { Kemampuan } \\
\text { Mengidentifikasi Potensi } \\
\left(\mathrm{Y}_{2.1}\right)\end{array}$ & $\begin{array}{c}\text { Kemampuan } \\
\text { Mengatasi Masalah } \\
\left(\mathbf{Y}_{2.2}\right)\end{array}$ \\
\hline $\begin{array}{l}\text { Ketepatan pelayanan penyuluhan Pertanian } \\
\left(\mathrm{Y}_{1.1}\right)\end{array}$ & $0,41641^{*}$ & 0,19271 \\
\hline Penampilan Penyuluh Pertanian $\left(\mathrm{Y}_{1.2}\right)$ & 0,7653 & 0,08119 \\
\hline
\end{tabular}

Sumber: Analisis Data Primer, 2011 
Jurnal Penyuluhan, September 2013 Vol. 9 No. 2

Tabel 10 Koefisien Korelasi Tingkat Kepuasan Petani dengan Kapasitas Petani

\begin{tabular}{|c|c|c|}
\hline $\begin{array}{l}\text { Tingkat Kepuasan } \\
\text { Petani }\end{array}$ & $\begin{array}{l}\text { Kemampuan Mengidentifikasi } \\
\text { Potensi Usahatani }\left(Y_{2.1}\right)\end{array}$ & $\begin{array}{l}\text { Kemampuan Mengatasi } \\
\text { Masalah }\left(Y_{2.2}\right)\end{array}$ \\
\hline $\begin{array}{l}\text { Intensitas Kunjungan Penyuluh } \\
\text { Pertanian }\left(\mathrm{X}_{2.1}\right)\end{array}$ & 0,26929 & 0,09994 \\
\hline Materi Penyuluhan $\left(\mathrm{X}_{2.2}\right)$ & 0,15802 & 0,20217 \\
\hline Metode Penyuluhan $\left(\mathrm{X}_{2.3}\right)$ & $0,31727^{*}$ & 0,28428 \\
\hline
\end{tabular}

Sumber: Analisis Data Primer, 2011

berkorelasi dengan kapasitas petani, baik kemampuan mengidentifikasi potensi usahatani, maupun kemampuan dalam mengatasi masalah. Dengan kata lain, kapasitas petani tidak terkait dengan karakteristik pribadi petani. Petani dengan karakteristik pribadi yang berbeda tidak membawa perbedaan yang berarti dalam hal kapasitasnya. Keadaan ini terjadi karena karakteristik pribadi petani tidak terlalu bervariasi dan keadaan lingkungan di Desa Sukadamai yang kurang mendorong petani untuk dapat mengembangkan kapasitasnya. Sebagian besar petani menjalani kehidupan sebagai rutinitas saja dan kurang tertantang untuk meningkatkan kapasitasnya sebagai petani.

Dilihat dari sudut kualitas pelayanan penyuluhan, terbukti bahwa intensitas kunjungan penyuluh, materi penyuluhan, serta metode penyuluhan berkorelasi positif secara nyata dengan tingkat kepuasan petani, khususnya ketepatan pelayanan penyuluhan pertanian, namun tidak berkorelasi dengan penampilan penyuluh (Tabel 8). Intensitas kunjungan, materi penyuluhan dan metode penyuluhan yang dilakukan penyuluh pertanian sangat menentukan ketepatan kegiatan penyuluhan pertanian. Semakin tinggi intensitas dari kunjungan penyuluh pertanian, semakin sesuai materi yang disampaikan penyuluh dengan kebutuhan petani, serta semakin sesuai metode penyuluhan yang diterapkan menyebabkan semakin meningkat kepuasan petani, khususnya dalam hal ketepatan pelayanan penyuluhan pertanian.

Ketepatan pelayanan penyuluhan pertanian ternyata berkorelasi positif secara nyata dengan kemampuan petani dalam mengidentifikasi potensi usahatani (Tabel 9). Artinya semakin tinggi nilai ketepatan pelayanan penyuluhan pertanian maka akan menyebabkan semakin tinggi pula tingkat kemampuan petani dalam mengidentifikasi potensi usahatani. Layanan penyuluhan yang tepat akan dapat memenuhi kebutuhan petani serta merubah perilaku petani ke arah yang diinginkan, diantaranya petani menjadi mampu mengidentifikasi potensi usahatani. Tidak demikian halnya dengan kemampuan mengatasi masalah karena masalah yang dihadapi petani umumnya bukan sematamata masalah yang menyangkut diri pribadi dan usahataninya, namun masalah yang menyangkut pihak lain, seperti masalah kesulitan dalam memasarkan hasil yang melibatkan pihak-pihak lain di luar petani. Dalam hubungannya dengan kepuasan para petani, ternyata tingkat kepuasan petani terhadap metode penyuluhan berkorelasi positif secara nyata dengan kemampuan petani dalam mengidentifikasi potensi usahatani (Tabel 10).

Kepuasan petani terhadap metode penyuluhan timbul karena dengan metode yang diterapkan, petani telah merasakan manfaat dari pelayanan penyuluhan yang dilakukan. Ketepatan metode penyuluhan juga menyebabkan petani dapat menerima dengan baik pesan-pesan dalam penyuluhan, termasuk caracara mengidentifikasi potensi usahatani yang ikut melibatkan kemampuan internal petani, namun ini tidak berkorelasi dengan kemampuan petani mengatasi masalah karena masalah utama yang sering dihadapi petani di Desa Sukadamai memang membutuhkan keterlibatan banyak pihak di luar para petani, yaitu untuk mengatasi permasalahan pemasaran produk usahatani petani.

\section{Kesimpulan}

Secara keseluruhan, kualitas pelayanan penyuluhan di Desa Sukadamai menurut penilaian para petani masih berada pada kategori sedang. Hal ini mengisyaratkan perlunya dilakukan pembenahan terhadap pelaksanaan penyuluhan pertanian di desa tersebut agar penyuluhan dapat berkualitas sehingga pertanian dapat lebih berkembang. Pada giliran selanjutnya, pengembangan pertanian dapat kembali meningkatkan keinginan masyarakat, terutama kaum 
muda untuk bekerja di bidang pertanian yang akhirakhir ini dipandang tidak menarik untuk ditekuni.

Peningkatan kualitas pelayanan penyuluhan pertanian akan menimbulkan kepuasan petani yang mendorong peningkatan kapasitas petani. Sehubungan dengan itu, unsur-unsur yang menentukan kualitas pelayanan penyuluhan perlu ditingkatkan terutama yang menurut penilaian petani masih belum optimal, yaitu intensitas kunjungan penyuluh perlu ditingkatkan, metode dan materi penyuluhan pertanian lebih disesuaikan dengan keadaan dan kebutuhan petani.

\section{Daftar Pustaka}

Abubakar AN, Siregar. 2010. Kualitas Pelayanan Penyuluhan dan Kepuasan Petani dalam Penanganan dan Pengolahan Hasil Ubi Jalar (Ipomoea batatas L.). Jurnal Penyuluhan Pertanian 5(1), Mei 2010.

Fatchiya A. 2010. Pola Pengembangan Kapasitas Pembudidayaan Ikan Kolam Air Tawar di Provinsi Jawa Barat. Disertasi. Bogor (ID): Sekolah Pascasarjana Institut Pertanian Bogor.

Mardikanto T. 1993. Penyuluhan Pembangunan Pertanian. Surakarta (ID): Sebelas Maret University Press.
Puspadi K. 2003. Restrukturisasi Sistem Penyuluhan Pertanian. Disertasi. Bogor (ID): Program Pascasarjana Institut Pertanian Bogor. Subagio H, Sumardjo, Pang S. Asngari, Prabowo Tjitropranoto, Djoko Susanto. 2008. Kapasitas Petani dalam Mewujudkan Keberhasilan Usaha Pertanian: Kasus Petani Sayuran di Kabupaten Pasuruan dan Kabupaten Malang Provinsi Jawa Timur. Jurnal Penyuluhan. 4(1). Bogor (ID): Institut Pertanian Bogor.

Syahyuti. 2006. KonsepPenting dalam Pengembangan Pedesaan dan Pertanian. Jakarta (ID): PT. Bina Rena Pariwara.

Tiraieyari NK. Idris A. Hamzah dan J Uli. 2010. Pentingnya Pengembangan Kompetensi Program Penyuluhan Pertanian, Agen Kinerja Proses Transfer Teknologi. Institut Ilmu Sosial Ilmu Pengetahuan, Universitas Putra Malaysia, 43400, Serdang, Selangor, Malaysia. American Journal of Ilmu Pertanian dan Biologi 5(3): 376-379, 2010 ISSN 1557-4989.

Tjitropranoto P. 2005. Konsep Pemahaman Diri, Potensi/Kesiapan Diri, dan Pengenalan Inovasi. Jurnal Penyuluhan. 1(1). Bogor (ID): Institut Pertanian Bogor.

Undang-undang Nomor 16 Tahun 2006. Sistem Penyuluhan Pertanian, Perikanan dan Kehutanan. 